\title{
Yield and Quality Response of Ryegrass, Egyptian Clover and Their Mixtures to Different Sources of Fertilizers
}

\author{
Alice Tawfik Thalooth1, Gaber Abd-Latif Sary², Haroon Mohamed El-Nagar2, \\ Mohamed Farouk El-Kramany ${ }^{1}$, Mohamed Omer Kabesh', Gehan Shaker Hanna Bakhoum ${ }^{1}$ \\ ${ }^{1}$ Field Crops Research Department, National Research Centre, Giza, Egypt \\ ${ }^{2}$ Agronomy Department, Faculty of Agriculture, Benha University, Benha, Egypt \\ Email: thaloothadel@yahoo.com
}

Received 2 December 2014; accepted 31 December 2014; published 24 January 2015

Copyright (C) 2015 by authors and Scientific Research Publishing Inc.

This work is licensed under the Creative Commons Attribution International License (CC BY).

http://creativecommons.org/licenses/by/4.0/

(c) (i) Open Access

\section{Abstract}

Two field experiments were conducted during two successive winter seasons of 2008/2009 and $2009 / 2010$ to investigate the potentialities of mixing Egyptian clover with ryegrass under bio, organic and mineral fertilization treatments and their combination to increase forage yield and quality grown under sandy soil conditions. The experiment included the combination of five mixing ratios (Egyptian clover alone, ryegrass alone, 75\% Egyptian clover: 25\% ryegrass, 50\% Egyptian clover: $50 \%$ ryegrass and $25 \%$ Egyptian clover: $75 \%$ ryegrass) and eight fertilizer sources, which include control, organic fertilization, bio fertilization, chemical fertilizer, organic + bio fertilizer, organic + chemical fertilizer, bio + chemical fertilizer and combination of organic and chemical and bio fertilizers. The obtained results indicate the superiority of $75 \%$ E. clover: $25 \%$ ryegrass mixture fertilized by Bio $+\mathrm{O}+\mathrm{N}$ in fresh and dry forage production. On the other hand, it reported the lowest dry weight of weeds $\mathrm{g} / \mathrm{m}^{2}$. Chemical analysis of forage plants showed that the mixture of $75 \%$ E. clover: $25 \%$ ryegrass surpassed that of other treatments yield for crude protein, ether extract and ash. The results also revealed that the highest record of DCP, crude fiber and TDNY was obtained by forage mixture of $75 \% \mathrm{E}$. clover: $25 \%$ ryegrass fertilized with Bio + 0 + N. Such higher yield of these characters has secured a balanced ratio which is really needed for ruminants ration.

\section{Keywords}

Rye Grass, Egyptian Clover, Forage Mixing Ratios, Organic, Bio and Chemical Fertilizers 


\section{Introduction}

Mixtures of forage crops (cereals and legumes) clearly have many advantages and are superior to their monocultures in providing greater yield and quality. In this respect grass-legume mixtures have high crude protein concentration and low fiber concentration than pure grass stand (Hamdollah et al. [1]).

Egyptian clover (Trifolium alexandrinum, L.) is considered the main winter forage legume in old and new lands of Egypt. This is due to its high yield and quality especially crude protein content. Ryegrass (Loliummulti floorum, L.) is a native annual winter grass and adapted to a wide varieties of soils and produce quick cover after cutting, of high production and quality. Thus, the principal benefits of mixing ryegrass (Loliummulti floorum, L.) with Egyptian clover (Trifolium alexndrinum, L.) are the increase of total dry matter production and forage quality [2]-[4].

Organic and bio fertilizers seem to be more appropriate agronomic practices as they are considered the important aspects in agronomic clean farming. Among these organic materials are crop residues, farmyard compost, green manure and bio fertilizer as microbial fertilizers and rhizobium, blue green algae and azolla. These are used to improve soil health and increased the yield which plays an important role for minimizing the harmful effect of pesticides and herbicides [5].

Thus, this study was designed to investigate the effect of different fertilization sources on forage yield, growth behavior and nutritive components of ryegrass, Egyptian clover and their mixtures at different ratios.

\section{Materials and Methods}

Two field experiments were conducted during two successive winter seasons of 2008/2009 and 2009/2010 in Research and Production Station, National Research Centre, Al-Nubaria District, Al Behaira Governorate, Egypt.

Experiments were conducted to investigate the response of the yield and yield components of Egyptian clover (Trifolium alexandrinum L.) var. Meskawy and ryegrass (Loliummulti florum) and their mixture in different rates to different sources of fertilizers under sandy soil conditions.

This experiment include forty treatments in three replicates which were combination of five mixing ratio (Egyptian clover alone, ryegrass alone, 75\% Egyptian clover: 25\% ryegrass, 50\% Egyptian clover: 50\% ryegrass and 25\% Egyptian clover: 75\% ryegrass) and eight fertilizer sources include (control, organic fertilization $\{20$ $\mathrm{m}^{3}$ chicken manure/fad.* $\left(*\right.$ fad. $=$ feddan $\left.\left.=4200 \mathrm{~m}^{2}\right)\right\}$ the chemical analysis of chicken manure is presented in Table 1, bio fertilization phosphorine and nitrobine) are commercial products of biofertilizers produced by General Organization of Agriculture Equalization Fund (GOAEF) oversight of Ministry of Agriculture, Egypt, mineral fertilization (N) $20 \mathrm{~kg} \mathrm{~N} /$ fad., bio + organic fertilization, organic + mineral (N) fertilization, bio fertilization + mineral $(\mathrm{N})$ fertilization and bio + organic fertilization + mineral $(\mathrm{N})$ fertilization.

Organic manure was mixed with the soil surface layer three days before sowing. Mineral Nitrogen fertilizer was added as ammonium sulfate $(20.6 \% \mathrm{~N})$ at a rate of $100 \mathrm{~kg} / \mathrm{fad}$. The nitrogen fertilizer was divided into three equal portions, the first was added before seeding and the second after the first cut while the third portion was added after the second cut.

Split plot design was used in three replicates where the mixture systems in the main plots and fertilization treatments in the sub plots. Phosphorus (P) and potassium (K) were applied to all the experimental plots at the recommended dose. Experimental field well prepared through two plouging and leveling then divided into experimental plots $3 \times 3.5=10.5 \mathrm{~m}^{2}$ (1/400 fad.).

Egyptian clover and ryegrass, and their mixtures were sown on 29 October 2008 and 3 November for the first and second seasons respectively. with the recommended seeding rate for Egyptian clover (20 kg seeds/fad.) and ryegrass (12 kg seeds/fad.) in sandy soil of district of Al-Nubaria region. The proceeding crop was sunflower in the two seasons the mechanical and chemical analyses of the experimental soil according to [6] are presented in Table 2.

E. clover seeds were inoculated with the specific Rhizobium strain. Three cuts were taken from each of the two seasons. First cut was at 60 days from seeding date, the second after 50 days from the first one and third cut was taken after 40 days from the second cut.

Samples of twenty randomly selected plants of E. clover and ryegrass and their mixtures were taken from each experimental plot from one $\mathrm{m}^{2}$ just before each cut to determine fresh and dry forage yields (kg/fed.), dry weight of weeds $\left(\mathrm{gm} / \mathrm{m}^{2}\right)$. Chemical analysis of forage quality components on dry weight basis was conducted 
Table 1. Chemical composition of the chicken manure used (average of 2008/2009 and 2009/2010 seasons).

\begin{tabular}{cccccccc}
\hline $\begin{array}{c}\text { Organic } \\
\text { matter \% }\end{array}$ & $\begin{array}{c}\text { Organic } \\
\text { carbon \% }\end{array}$ & C/N ratio & $\mathrm{pH}$ & $\begin{array}{c}\mathrm{EC} \\
\mathrm{mmhos} / \mathrm{cm}^{3}\end{array}$ & $\mathrm{~N} \%$ & $\begin{array}{c}\mathrm{P} \\
\mathrm{ppm}\end{array}$ & $\begin{array}{c}\mathrm{K} \\
\mathrm{ppm}\end{array}$ \\
\hline 50.35 & 29.20 & 14.4 & 7.6 & 8.20 & 2.08 & 118 & 108
\end{tabular}

Table 2. Mechanical and chemical analyses of the experimental soil (average of 2008/2009 and 2009/2010 seasons).

\begin{tabular}{cccc}
\hline \multicolumn{1}{c}{ Mechanical analysis } & \multicolumn{2}{c}{ Chemical analysis } \\
\hline Sand \% & 92.3 & Organic matter \% & 0.3 \\
Silt \% & 3.1 & E. C. mmhos/cm ${ }^{3}$ & 0.3 \\
$\mathrm{Clay} \%$ & 4.6 & $\mathrm{pH}$ & 7.4 \\
$\mathrm{CaCO}_{3} \%$ & 1.3 & Soluble N, ppm & 8.0 \\
Soil texture & Sandy & Available P, ppm & 3.0 \\
& & Exchan. K, ppm & 19.8 \\
\hline
\end{tabular}

for each treatment to determine crude protein. Total nitrogen percentage was determined according to [7] and the crude protein content was estimated by multiplying the analyzed total nitrogen percent by $6.25 \%$ for clover pure; by $6.125 \%$ for clover $75 \%$ : $25 \%$ ryegrass mixture, by $6.00 \%$ for $50 \%$ clover: $50 \%$ ryegrass mixture, by $5.875 \%$ for $25 \%$ clover: $75 \%$ ryegrass and by $5.75 \%$ for ryegrass pure. Crude fiber, ether extract (EE): (crude fats) and ash were estimated according to A.O.A.C [8].

Nutritive evaluation of feedstuff samples for forage material of the different treatments was also estimated. Digestible Crude Protein (DCP) and Total Digestible Nutrients (TDN) were calculated according to the equation of [9].

Data were statistically analyzed according to [10] the combined analysis was conducted for the data of the two growing seasons, the least significant differences (LSD) at the level of 5\% significance was used to compare the treatments mean [11].

\section{Results and Discussion}

\subsection{Forage Yield (ton/fad.)}

\subsubsection{Fresh and Dry Yield}

Fresh forage yield as affected by the different E. clover, ryegrass and their mixtures fertilized with the applied treatments is presented in Table 3. Results indicated the superiority of $75 \%$ E. clover: $25 \%$ ryegrass mixture, fertilized by Bio $+\mathrm{O}+\mathrm{N}$ in fresh forage production. The same effect of the interaction was obtained with dry forage yield. The highest fresh forage yield was 16.598, 16.120 and 13.15 ton/fad. and the highest dry forage yield from such interaction effect was 1.560, 2.758 and 4.110 ton/fad. for the subsequent three cuts respectively. These results were similar to those obtained by [3] [12]-[14]. These results may be due to the effect of Rhizobium bacteria on nodules of E. clover roots and its effect in fixing nitrogen from the ambient air beside the integrated effect of Bio $+\mathrm{O}+\mathrm{N}$ fertilizers. In this respect, [15] found that E. clover-ryegrass mixture inoculated with Rhizobium and mixture of $\mathrm{N}$-fixing bacteria produced higher fresh yield. [16] added that the application of organic fertilizer increased the obtained green and dry mass by 20.43 more than the untreated standard crop.

\subsubsection{Dry Weight of Weeds}

It is clear from data in Table 3 that dry weight of weeds $\mathrm{g} / \mathrm{m}^{2}$ were decreased through the subsequent three cuts either in mono culture or their mixtures of E. clover and ryegrass. Treatment of Bio $+\mathrm{O}+\mathrm{N}$ recorded the lowest dry weight of weeds $\mathrm{g} / \mathrm{m}^{2}$.

The least dry weight $\left(\mathrm{g} / \mathrm{m}^{2}\right)$ was obtained for mono culture of ryegrass fertilized with Bio $+\mathrm{O}+\mathrm{N}$. The low intensity of weed infection could be due to the highest competition of pure ryegrass than the invaded weed, due to heaviest covering of ryegrass which shades the invaded weed and limits it growth and survival.

The same above fertilizer treatment produced more dry weed intensity in E. clover pure stand as compared 
Table 3. Effect of Interaction of berseem, ryegrass, their mixtures and fertilization on fresh and dry forage yield and dry weeds (combined over two seasons 2008/2009 and 2009/2010).

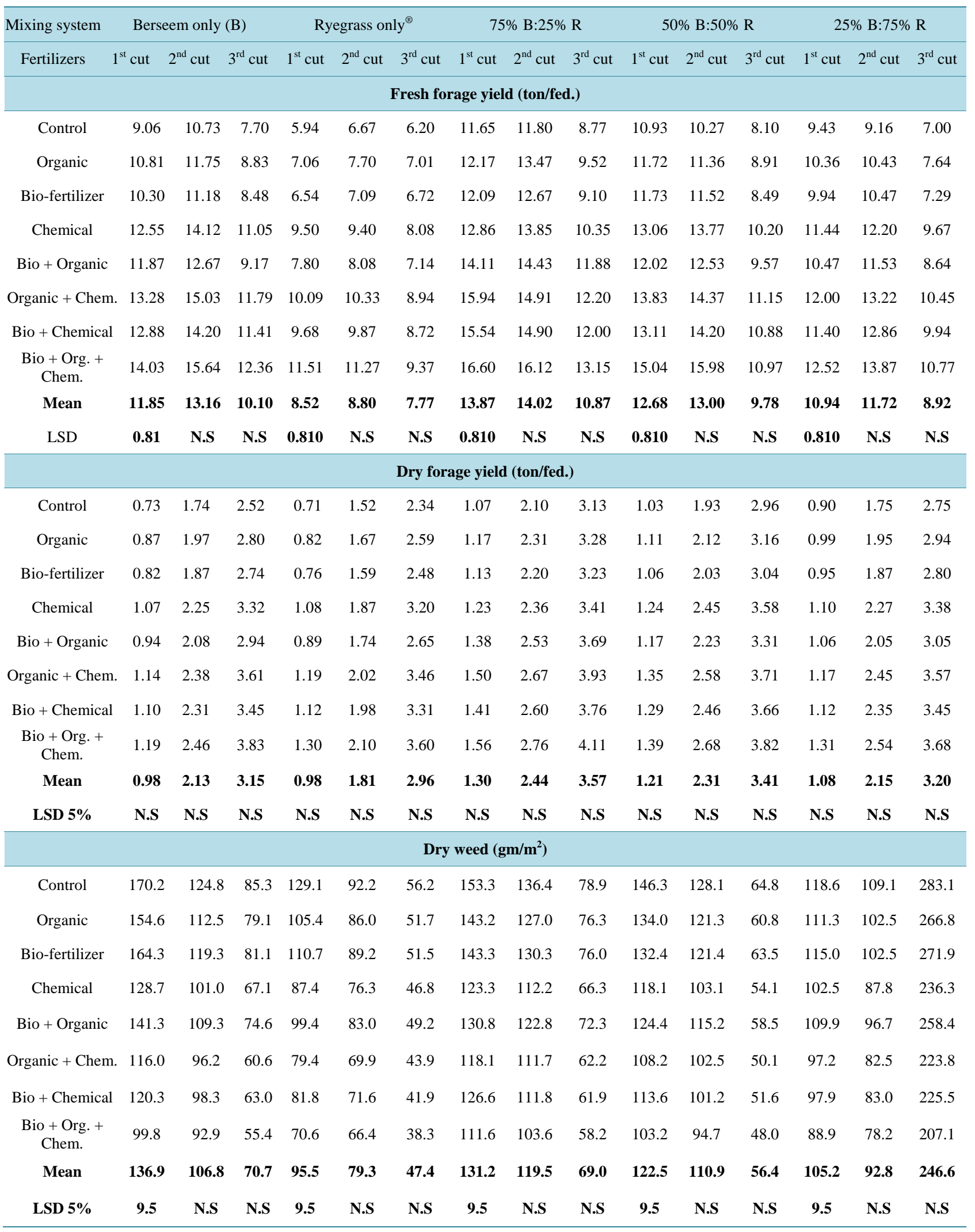


with ryegrass in the pure stand as it is clear in Table 3. So, the competition of E. clover in its pure stand was not as much as ryegrass in its pure stand. [17] came to the same results.

\subsection{Chemical Constituents and Nutritive Value of Forage Plants}

\section{A-Crude Protein (CP)}

The effect of the interaction between forage mixtures and different sources of fertilizer on the crude protein (kg/fad.) is shown in Table 4. The obtained results showed that more CP content was detected in all forage plants under experimentation for their later cuts than earlier ones. The obtained results also showed that the mixture of $75 \%$ E. clover: $25 \%$ ryegrass surpassed that other mixtures under different sources of fertilization treatments. Similar results were reported by [18] [19].

The highest of the CP yield (578 kg/fad.) recorded by E. clover fertilized with combination of Bio + Org. + Chem. fertilizer treatment. Such increase of CP yield under different sources of fertilizers may be attributed to the increase in the concentration of available nitrogen in root medium as a result of mineral $\mathrm{N}$ fertilizer. Similar findings were recorded by [20]-[22].

\section{B-Crude Fiber}

The obtained results in Table 4 indicated CF yield (kg/fad.). Data clarified that, in general, CF yield (kg/fad.) of the proposed binary forage mixtures was higher for the later cut (third cut) than the earlier cuts. These results were true under applications of chemical types of fertilizer and their combinations. Here it is noticed that the highest CF content (910.29 kg/fad.) was obtained by forage mixture of $75 \%$ E. clover: $25 \%$ ryegrass under fertilization with Bio + Org. + Chem. Such effect may be attributed to the grasses with its nature of stemming structure. In this respect, [23] and [24] reported that grasses have much higher hemicellulose. Similar results were recorded by [25] and [26]. Such higher yield of CF of $75 \%$ E. clover: $25 \%$ ryegrass mixture under the combined source of fertilizers is responsible for a number of benefits beside the higher production of yield and quality as securing balanced ratio concerning crude protein and energy which is really needed for ruminants ration.

\section{C-Ash Content}

It is clear from Table 4 that ash content increased obviously from the earlier cut to later one. Such effect may be attributed to the increase in dry matter accumulation by ageing. The obtained results also showed that $75 \% \mathrm{E}$. clover: $25 \%$ ryegrass (629.62 kg/fad.) surpassed that of other mixture treatment under the combined sources of fertilizers. Results obtained by [27] and [26] are similar to those findings in this work.

\section{D-Ether Extract (EE)}

It should notice that EE content represent slightly smaller values of narrow ignorable ranges. Meanwhile, the obtained results were fluctuating with no specific trend as its clear for Table 5. But, it is generally noticed that the interaction of Bio $+\mathrm{O}+\mathrm{N}$ fertilization treatment produced higher EE content for the mixture of $75 \%$ E. clover: $25 \%$ ryegrass with significantly in the last two cuts. These results are in agreement with those obtained by [27] [28].

\section{E-DCP Yield}

Data of digestible crude protein DCP yield of the proposed forage mixtures for all cuts under various fertilizers are presented in Table 5. The obtained results revealed that DCP content obviously increased from the earlier to the latest cuts. These results were confirmed for all forage plants mixtures and under all sources of fertilizers. However, the highest record of DCP yield ( $390.24 \mathrm{~kg} / \mathrm{fad}$.) was obtained by forage mixture $75 \%$ E. clover: $25 \%$ ryegrass fertilized with Bio $+\mathrm{O}+\mathrm{N}$ in the third cut. These results could be used in upgrading quality of the assigned forage mixture through selecting the appropriate association of botanical components. Similar results obtained by [29] and [22].

\section{F-Total Digestible Nutrient Yield (TDNY)}

Data presented in Table 5 revealed that TDNY of the pure stand of either ryegrass or E. clover and their mixture of forage under the different fertilization treatments were noticeably higher for the earlier than the later cuts. This could be due to the higher leaf/ stem ratio of such forage plants for early cuts compared by the leaf/stem ratio of the later cuts. These results could be due to the prevailing environmental factors and plants age which play an important role in reducing the TDNY of the forage resulting from more deposited fibers and/or lignin with some of the other anti-quality components (as lignin) that may reduce TDNY (kg/fad.) of the obtained forages. Data also show that the highest TDNY content (kg/fad.) was recorded by forage mixture of $75 \%$ E. clover: $25 \%$ ryegrass under Bio $+\mathrm{O}+\mathrm{N}$ treatment. These results were confirmed by [29] and [22]. 
Table 4. Effect of Interaction of berseem, ryegrass, their mixtures and fertilization on crude protein, crude fiber and fiber content (combined over two seasons 2008/2009 and 2009/2010).

\begin{tabular}{|c|c|c|c|c|c|c|c|c|c|c|c|c|c|c|c|c|}
\hline \multirow{2}{*}{$\begin{array}{c}\begin{array}{c}\text { Mixing } \\
\text { system }\end{array} \\
\text { Fertilizers }\end{array}$} & \multicolumn{2}{|c|}{ Berseem only (B) } & \multicolumn{4}{|c|}{ Ryegrass only $^{\circledR}$} & \multicolumn{4}{|c|}{$75 \%$ B:25\% R } & \multicolumn{3}{|c|}{$50 \%$ B:50\% R } & \multicolumn{3}{|c|}{ 25\% B:75\% R } \\
\hline & $2^{\text {nd }}$ & cut $3^{\text {rd }}$ & cut & cut $2^{n}$ & cut $3^{\mathrm{rc}}$ & cut & ${ }^{\text {st }}$ cut & & ${ }^{\text {ad }}$ cut 3 & $3^{\text {rd }}$ cut & $1^{\text {st }}$ cut & $2^{\text {nd }}$ cut & $3^{\text {rd }}$ cut & $1^{\text {st }}$ cut & $2^{\text {nd }}$ cut & $3^{\text {rd }}$ cut \\
\hline \multicolumn{17}{|c|}{ A-Crude protein content (kg/fed.) } \\
\hline Control & 143.11 & 323.06 & 385.98 & 93.66 & 187.30 & 226.77 & 198 & & 354.17 & $7 \quad 386.37$ & 7185.40 & 270.40 & 351.16 & 143.17 & 231.43 & 308.17 \\
\hline Organic & 174.82 & 376.52 & 448.66 & 114.74 & 210.64 & 259.97 & 228 & & 394.08 & $8 \quad 423.18$ & 3203.26 & 311.63 & 391.13 & 149.90 & 262.12 & 348.80 \\
\hline Bio-fertilizer & 160.03 & 349.57 & 430.21 & 104.28 & 196.21 & 289.28 & 215 & & 374.16 & 6406.52 & 188.84 & 284.51 & 364.65 & 142.99 & 247.01 & 317.58 \\
\hline Chemical & 223.72 & 454.91 & 559.93 & 164.61 & 250.28 & 357.15 & 275 & & 454.35 & $5 \quad 505.28$ & 3236.95 & 374.65 & 471.81 & 183.44 & 317.36 & 414.03 \\
\hline Bio + Organic & 192.17 & 402.73 & 467.27 & 131.35 & 222.38 & 282.82 & 244 & & 411.24 & $4 \quad 449.74$ & 4214.96 & 329.79 & 414.58 & 161.52 & 278.39 & 363.42 \\
\hline Organic + Chem. & 248.64 & 487.71 & 612.89 & 187.67 & 272.05 & 394.01 & 304 & & 494.48 & 8550.06 & 258.37 & 408.04 & +496.99 & 199.62 & 348.63 & 442.19 \\
\hline Bio + Chemical & 234.76 & 468.47 & 574.03 & 175.02 & 261.99 & 404.11 & 282 & & 472.15 & $5 \quad 517.35$ & 246.65 & 378.03 & 482.74 & 186.95 & 332.35 & 420.56 \\
\hline $\begin{array}{c}\text { Bio + Org. + } \\
\text { Chem. }\end{array}$ & 258.04 & 512.52 & 657.50 & 207.32 & 285.49 & 419.83 & 317 & & 498.36 & $6 \quad 578.01$ & 1266.97 & 431.70 & 518.66 & 220.81 & 371.26 & 458.06 \\
\hline Mean & 204.41 & 421.94 & 517.06 & 147.33 & 235.79 & 329.24 & 258 & & 431.62 & 2477.06 & क 225.17 & 348.59 & 436.46 & 173.55 & 298.57 & 384.10 \\
\hline LSD & 18.17 & 24.05 & 26.04 & 18.17 & 24.05 & 26.04 & 18. & & 24.05 & 26.04 & 18.17 & 24.05 & 26.04 & 18.17 & 24.05 & 26.04 \\
\hline \multicolumn{17}{|c|}{ B-Crude fiber content (kg/fed.) } \\
\hline Control & 97.24 & 265.06 & 428.31 & 118.72 & 295.57 & 470.69 & 161 & & 390.72 & 2596.60 & 157.96 & 345.53 & 565.46 & 145.67 & 310.71 & 529.31 \\
\hline Organic & 138.57 & 343.20 & 518.41 & 154.94 & 335.16 & 532.16 & 193. & & 454.13 & 3673.25 & 194.00 & 412.78 & 631.87 & 169.41 & 349.34 & 611.05 \\
\hline Bio-fertilizer & 121.52 & 346.78 & 523.18 & 136.50 & 315.57 & 597.84 & 184 & & 420.59 & 9633.38 & 3179.07 & 392.80 & 628.11 & 158.16 & 324.76 & 595.56 \\
\hline Chemical & 179.74 & 438.61 & 676.94 & 201.09 & 379.50 & 716.43 & 243. & & 513.91 & 1766.90 & 224.29 & 494.73 & 782.92 & 205.55 & 481.88 & 742.06 \\
\hline Bio + Organic & 143.20 & 401.83 & 587.76 & 163.75 & 341.82 & 560.17 & 213. & & 474.72 & 2678.09 & 207.53 & 436.23 & 696.79 & 193.71 & 427.47 & 669.26 \\
\hline Organic + Chem. & 207.51 & 469.70 & 772.07 & 236.00 & 445.18 & 806.75 & 276. & & 550.00 & D 877.93 & 251.90 & 528.74 & 836.71 & 230.10 & 528.21 & 788.87 \\
\hline Bio + Chemical & 197.83 & 430.74 & 734.78 & 219.90 & 428.10 & 850.65 & 244. & & 505.40 & 822.12 & 239.18 & 526.40 & 810.38 & 210.00 & 489.33 & 777.33 \\
\hline $\begin{array}{l}\text { Bio + Org. + } \\
\text { Chem. }\end{array}$ & 228.39 & 499.11 & 849.82 & 258.48 & 487.79 & 881.39 & 280 & & 555.73 & 3910.29 & 274.48 & 579.35 & 853.99 & 271.88 & 557.11 & 870.57 \\
\hline Mean & 164.25 & 399.38 & 636.41 & 186.17 & 378.59 & 677.01 & 224. & & 483.15 & 744.82 & 216.05 & 464.57 & 725.78 & 198.06 & 433.60 & 698.00 \\
\hline LSD & 18.20 & 31.88 & 43.56 & 18.20 & 31.88 & 43.56 & 18.2 & & 31.88 & 43.56 & 18.20 & 31.88 & 56 & 3.20 & 31.88 & 43.56 \\
\hline \multicolumn{17}{|c|}{ C-Ash content (kg/fed.) } \\
\hline Control & 124.61 & 255.27 & 293.74 & 107.03 & 206.27 & 251.36 & 183. & & 288.96 & 6385.76 & 168.07 & 276.25 & 330.47 & 147.48 & 240.65 & 273.36 \\
\hline Organic & 154.40 & 301.24 & 391.74 & 142.56 & 246.61 & 330.85 & 191. & & 335.89 & 9 389.71 & 188.26 & 317.99 & 418.22 & 164.29 & 278.47 & 343.51 \\
\hline Bio-fertilizer & 141.52 & 269.07 & 356.38 & 116.35 & 236.21 & 330.33 & 191. & & 333.53 & 3419.55 & 169.10 & 307.28 & 371.69 & 155.40 & 260.74 & 320.53 \\
\hline Chemical & 192.49 & 378.64 & 431.86 & 183.10 & 281.92 & 413.32 & 259. & & 413.14 & $4 \quad 523.31$ & 221.67 & 396.13 & 508.69 & 191.25 & 372.86 & 432.00 \\
\hline Bio + Organic & 181.44 & 318.37 & 435.53 & 147.35 & 259.69 & 330.89 & 208. & & 374.71 & 1468.25 & 205.37 & 355.31 & 442.33 & 182.99 & 311.27 & 378.71 \\
\hline Organic + Chem. & 217.89 & 419.87 & 540.04 & 214.94 & 334.25 & 453.57 & 282. & & 450.95 & $5 \quad 617.18$ & 246.15 & 423.03 & 532.27 & 210.71 & 414.91 & 464.82 \\
\hline Bio + Chemical & 197.19 & 400.72 & 528.31 & 192.68 & 315.84 & 491.74 & 240. & & 455.97 & $7 \quad 548.55$ & 233.46 & 409.68 & 517.37 & 196.89 & 392.32 & 438.23 \\
\hline $\begin{array}{c}\text { Bio + Org. + } \\
\text { Chem. }\end{array}$ & 220.45 & 460.90 & 606.00 & 239.90 & 340.98 & 498.00 & 308. & & 497.97 & 7629.62 & 263.99 & 456.90 & 575.43 & 248.26 & 429.01 & 487.81 \\
\hline Mean & 178.75 & 350.51 & 447.95 & 167.99 & 277.72 & 387.51 & 233. & & 393.89 & $\begin{array}{l}9 \\
497.74\end{array}$ & 212.01 & 367.82 & 462.06 & 187.16 & 337.53 & 392.37 \\
\hline LSD $5 \%$ & 17.74 & 24.65 & 27.76 & 17.74 & 24.65 & 27.76 & 17.7 & & 24.65 & 27.76 & 17.74 & 24.65 & 27.76 & 17.74 & 24.65 & 27.76 \\
\hline
\end{tabular}


Table 5. Effect of Interaction of berseem, ryegrass, their mixtures and fertilization on total digestible nutrient TDN, digestible crude protein and ether extract content (combined over two seasons 2008/2009 and 2009/2010).

\begin{tabular}{|c|c|c|c|c|c|c|c|c|c|c|c|c|c|c|c|}
\hline \multirow{2}{*}{\begin{tabular}{|c|}
$\begin{array}{c}\text { Mixing } \\
\text { system }\end{array}$ \\
Fertilizers \\
\end{tabular}} & \multicolumn{2}{|c|}{ Berseem only (B) } & \multicolumn{4}{|c|}{ Ryegrass only $^{\circledR}$} & \multicolumn{3}{|c|}{$75 \%$ B:25\% R } & \multicolumn{2}{|c|}{$50 \%$ B:50\% R } & \multicolumn{4}{|c|}{$25 \%$ B:75\% R } \\
\hline & it $2^{\text {nd }} \mathrm{cu}$ & ut $3^{\text {rd }} \mathrm{c}$ & cut $1^{\text {st }} \mathrm{C}$ & cut 2 & cut $3^{\text {rd }}$ & cut $1^{\text {st }}$ & $1^{\text {st }}$ cut $2^{1}$ & $2^{\text {nd }}$ cut $3^{\text {r }}$ & $3^{\text {rd }}$ cut $1^{\text {s }}$ & $1^{\text {st }}$ cut 2 & $2^{\text {nd }}$ cut 3 & $3^{\text {rd }}$ cut & $1^{\text {st }}$ cut & $2^{\text {nd }}$ cut & ${ }^{\text {rd }}$ cut \\
\hline \multicolumn{16}{|c|}{ D—Ether extract content (kg/fed.) } \\
\hline Control & 13.73 & 36.25 & 32.65 & 16.03 & 33.09 & 36.51 & 24.51 & 37.51 & 46.49 & 20.61 & 46.36 & 32.36 & 20.26 & 35.51 & 42.22 \\
\hline Organic & 20.41 & 46.51 & 38.67 & 24.20 & 49.32 & 45.56 & 29.60 & 46.90 & 51.06 & 24.52 & 46.66 & 54.86 & 24.65 & 45.82 & 54.17 \\
\hline Bio-fertilizer & 17.69 & 42.07 & 36.44 & 18.92 & 43.76 & 57.64 & 27.27 & 44.40 & 51.24 & 22.73 & 43.33 & 48.47 & 23.35 & 43.53 & 51.40 \\
\hline Chemical & 29.88 & 53.85 & 63.70 & 40.09 & 61.79 & 75.44 & 40.35 & 70.19 & 71.60 & 30.87 & 62.63 & 73.44 & 35.41 & 62.13 & 71.55 \\
\hline Bio + Organic & 23.13 & 51.93 & 54.78 & 24.32 & 52.00 & 57.58 & 31.96 & 55.37 & 59.27 & 27.78 & 52.69 & 64.15 & 30.46 & 1.30 & 60.65 \\
\hline Organic + Chem. & 35.17 & 61.05 & 72.64 & 45.84 & 57.27 & 103.05 & 45.41 & 76.80 & 83.01 & 38.84 & 67.29 & 86.17 & 39.94 & 72.52 & 86.51 \\
\hline Bio + Chemical & 27.60 & 51.83 & 67.98 & 44.53 & 54.55 & 105.06 & 43.78 & 75.15 & 77.87 & 34.48 & 68.30 & 79.14 & 37.30 & 68.82 & 73.45 \\
\hline $\begin{array}{l}\text { Bio + Org. + } \\
\text { Chem. }\end{array}$ & 34.83 & 66.29 & 79.06 & 53.97 & 56.82 & 114.13 & 53.34 & 81.08 & 91.80 & 40.58 & 88.42 & 91.25 & 51.38 & 77.00 & 90.38 \\
\hline Mean & 25.31 & 51.22 & 55.74 & 33.49 & 51.07 & 74.37 & 37.03 & 60.93 & 66.54 & 30.05 & 59.46 & 66.23 & 32.84 & 57.08 & 66.29 \\
\hline LSD 5\% & 3.16 & 4.15 & 4.20 & 3.16 & 4.15 & 4.20 & 3.16 & 4.15 & 4.20 & 3.16 & 4.15 & 20 & .16 & 4.15 & 4.20 \\
\hline \multicolumn{16}{|c|}{ e-Digestible crude protein content ( $\mathrm{kg} / \mathrm{fed}$.) } \\
\hline Control & 104.35 & 232.55 & 267.62 & 263.30 & 121.98 & 8143.91 & -1 143.17 & $17 \quad 249.48$ & $18 \quad 251.81$ & $31 \quad 132.05$ & $5 \quad 183.16$ & $6 \quad 226.00$ & $0 \quad 89.28$ & 154.00 & 194.29 \\
\hline Organic & 127.80 & 272.16 & 313.88 & $8 \quad 78.43$ & $3 \quad 138.11$ & 1165.89 & 39166.02 & $02 \quad 277.78$ & $78 \quad 279.46$ & $6 \quad 145.13$ & $13 \quad 213.59$ & $9 \quad 255.01$ & 1104.25 & $5 \quad 175.11$ & 224.03 \\
\hline Bio-fertilizer & 116.52 & 251.70 & 299.62 & 271.06 & 5 $\quad 127.84$ & $4 \quad 184.46$ & $46 \quad 155.66$ & $\begin{array}{ll}66 \quad 263.89\end{array}$ & $39 \quad 266.48$ & $18 \quad 134.25$ & $25 \quad 192.75$ & $5 \quad 235.45$ & $5 \quad 99.12$ & 164.28 & 200.90 \\
\hline Chemical & 164.35 & 331.76 & 395.58 & $8 \quad 114.32$ & $2 \quad 166.80$ & $0 \quad 233.12$ & $12 \quad 200.45$ & $45 \quad 323.84$ & $34 \quad 338.93$ & 3170.62 & $52 \quad 258.72$ & 2313.07 & $7 \quad 129.76$ & $5 \quad 214.06$ & 269.89 \\
\hline Bio + Organic & 140.81 & 291.72 & 326.19 & $9 \quad 90.78$ & $8 \quad 146.33$ & 3183.78 & $78 \quad 177.86$ & $36 \quad 301.25$ & $25 \quad 298.72$ & 2153.68 & $58 \quad 226.23$ & $3 \quad 271.25$ & $5 \quad 112.14$ & $4 \quad 186.45$ & 233.78 \\
\hline Organic + Chem. & 183.83 & 356.41 & 433.38 & $8 \quad 128.9$ & 4181.50 & $0 \quad 258.12$ & $12 \quad 222.75$ & $75 \quad 354.44$ & $14 \quad 370.99$ & 9186.10 & $10 \quad 284.06$ & $6 \quad 331.12$ & 2141.78 & 3236.18 & 287.74 \\
\hline Bio + Chemical & 173.03 & 341.88 & 304.17 & $7 \quad 122.30$ & $0 \quad 174.04$ & $4 \quad 263.16$ & $16 \quad 206.42$ & $42 \quad 337.22$ & $22 \quad 347.42$ & $12 \quad 177.63$ & $53 \quad 264.45$ & $5 \quad 320.43$ & 3132.27 & $7 \quad 224.78$ & 272.21 \\
\hline $\begin{array}{l}\text { Bio + Org. + } \\
\text { Chem. }\end{array}$ & 190.52 & 375.52 & 465.73 & $3 \quad 145.15$ & 5191.00 & $0 \quad 276.45$ & $45 \quad 232.36$ & $36 \quad 344.03$ & 3390.24 & 4193.56 & $56 \quad 301.63$ & 3347.05 & $5 \quad 156.29$ & 253.11 & 298.45 \\
\hline Mean & 150.15 & 306.71 & 363.27 & $7 \quad 101.78$ & $8 \quad 155.95$ & $5 \quad 213.61$ & 61188.09 & $09 \quad 306.49$ & 19318.01 & 1161.63 & 63240.57 & $7 \quad 287.42$ & 2120.61 & 1201.00 & 247.66 \\
\hline LSD 5\% & N.S & 16.64 & 17.20 & N.S & 16.64 & $4 \quad 17.20$ & N.S & 16.64 & $4 \quad 17.20$ & N.S & 16.64 & 17.20 & N.S & 16.64 & 17.20 \\
\hline \multicolumn{16}{|c|}{ F-Total digestible nutrient TDN content (kg/fed.) } \\
\hline Control & 456.401 & 1063.311 & 1524.98 & 452.06 & 955.32 & 1444.37 & 7677.42 & 1301.27 & 71914.15 & 5661.93 & 31218.60 & 1830.17 & 7581.67 & 10 & 170 \\
\hline Organic & 558.761 & 1228.981 & 1730.40 & 545.10 & 1075.48 & 1643.61 & 1755.94 & 41462.81 & 12027.86 & 6737.15 & $5 \quad 1370.47$ & 71972.79 & 9663.55 & 1273.35 & 1846.76 \\
\hline Bio-fertilizer & 521.271 & 1158.931 & 1686.33 & 501.94 & 1017.36 & 1757.82 & 725.12 & 1386.33 & 31983.70 & $0 \quad 690.22$ & 21306.20 & 1888.75 & 5637.68 & 1217.18 & 1749.44 \\
\hline Chemical & 713.581 & 1474.992 & 2082.64 & 762.21 & 1274.87 & 2117.60 & 942.95 & 1666.13 & 32320.83 & 3849.03 & 3 1628.27 & 72301.58 & 8719.52 & 1349.72 & 1944.99 \\
\hline Bio + Organic & 611.051 & 1306.861 & 1825.30 & 599.28 & 1133.26 & 1693.62 & 2811.68 & 1503.20 & 02126.48 & 8781.68 & $\begin{array}{ll}8 & 1451.17\end{array}$ & 72079.84 & 4765.68 & 1522.26 & 2183.82 \\
\hline Organic + Chem. & 769.041 & 1575.202 & 2285.31 & 846.86 & 1401.48 & 2325.99 & 1035.30 & 01792.10 & 02503.41 & 1934.74 & $4 \quad 1729.12$ & 2412.43 & 3822.81 & 1659.14 & 2337.10 \\
\hline Bio + Chemical & 737.501 & 1524.602 & 2169.71 & 793.86 & 1367.29 & 2383.74 & 4969.16 & 1733.94 & 42378.20 & $0 \quad 889.97$ & $7 \quad 1642.17$ & 72361.62 & 2784.05 & 1580.96 & 2239.22 \\
\hline Bio + Org + Chem. & 819.731 & 1662.352 & 2471.50 & 943.48 & 1471.37 & 2454.94 & 41085.06 & 61908.13 & 32673.14 & 4976.06 & 61806.32 & 2515.66 & 6927.43 & 1729.36 & 2440 \\
\hline Mean & 648.421 & 1374.401 & 1972.02 & 680.60 & 1212.05 & 1977.71 & 1875.33 & 1594.24 & 42240.97 & 7815.10 & o 1519.04 & 42170.35 & 5737.80 & 1428.06 & 2056.39 \\
\hline LSD & N.S & N.S & 129.17 & N.S & N.S & 129.17 & N.S & N.S & 129.17 & N.S & N.S & 129.17 & N.S & N.S & 129.17 \\
\hline
\end{tabular}




\section{Conclusion}

From the obtained results, it could be concluded that mixing $75 \%$ E. clover with $25 \%$ ryegrass and fertilized with Bio $+\mathrm{O}+\mathrm{N}$ fertilizers could be recommended for better forage quantity and quality. Thus, it is beneficial in future to increase areas of such forage mixing ratio under the combined three fertilizers in sandy soils for many reasons which include saving good soils for other crops, improving soil properties as a result of Egyptian clover cultivation, and obtaining better forage in quantity and quality for animal feeding.

\section{References}

[1] Hamdollah, E., Ahmad, G. and Abdollah, J. (2009) Intercropping of Cereals and Legumes for Forage Production. Notulae Scientia Biologicae, 1, 7-13.

[2] Ghaffarzadeh, M. (1997) Economic and Biological Benefits of Intercropping Berseem Clover with Oat in CornSoybean-Oat Rotation. Journal of Production Agriculture, 10, 314-319. http://dx.doi.org/10.2134/jpa1997.0314

[3] Ramadan, A.W. (1997) Response of Berseem-Ryegrass Mixture to Fertilization. M.Sc. Thesis, Ain Shams University, Cairo.

[4] James J., Beth, W. and Joan, Mc.K. (1998) Forage Production from Spring Cereals and Cereal-Pea Mixtures. Ministry of Agriculture Food \& Rural Affairs C.F., Ontario. http://www.omafra.gov.on.ca/english/crops/facts/98-041.htm

[5] Ananata, G. (2002) A Review on Organic Farming for Sustainable. Agriculture B.Sc. (Ag.), Final Year Exam Roll No: 32.

[6] Jackson, M.L. (1960) Soil Chemical Analysis. Prentice, Engleweed Cliff, 183-190.

[7] Chapman, H.D. and Pratt, P.F. (1978) Methods of Analysis for Soils, Plants and Water. Univ. of California, Prical Publication, Vol. 4030, 12-19.

[8] A.O.A.C. (2000) Official Methods of Analysis. 17th Edition, Association of Official Analytical Chemists, Washington DC.

[9] N.R.C. (1977) Nutrient Requirements of Rabbits. National Research Council, Washington DC.

[10] Snedecor, G.W. and Cochran, W.G. (1990) Statical Methods. 8th Edition, Iowa State Univ. Press, Ames.

[11] Steel, R.G., Torrie, J.H. and Dickey, D.A. (1980) Principles and Procedures of Statistics: A Biometrical Approach. 2nd Edition, McGraw-Hill Book Co., Inc., New York.

[12] Butler, T.J. and Muir, J.P. (2012) Perspective on Forage Legume Systems for the Tallgrass and Mixed-Grass Prairies of the Southern Great Plains of Texas and Oklahoma. Crop Science, 52, 1971-1979. http://dx.doi.org/10.2135/cropsci2011.12.0674

[13] EL-Kramany, M.F., Elewa, T.A. and Bakry, A.B. (2012) Effect of Mixture Rates of Forage Mixtures of Egyptian Clover (Trifolium alexandrinum L.) with (Triticosecale wittmack) under Newly Reclaimed Sandy Soil. Australian Journal of Basic and Applied Sciences, 6, 40-44.

[14] Thalooth, A.T., Bahr Amany, A. and Tawfik, M.M. (2012) Productivity of Some Barley Cultivars as Affected by Inoculation under Water Stress Conditions. Elixir Applied Botany, 51, 10743-10749.

[15] Mousa, M. and El-Nabawi, E.S. (1995) Effect of Bacterial Inoculationon Forage Yield of Berseem-Ryegrass Mixture. Zagazig Journal of Agricultural Research, 22, 367-376.

[16] Lingorski, V. (2012) Influence of Foliar Top Dressing with Organic Fertilizer on Some Bioproductive Forage Parameters of Annual Summer Cereal-Leguminous Mixed Crop. Banat's Journal of Biotechnology, 3, 32-36.

[17] Zaghloul, A.K. (1995) Forage Yield of Egyptian Clover as Affected by Mixing and Fertilization. Ph.D. Thesis, Department of Agronomy, Faculty of Agriculture Sciences Moshtohor (Banha Branch), Zagazig University, Zagazig.

[18] Patel, J.R. and Rajagopal, S. (2003) Response of Berseem (Trifolium alexandrinum) to Nitrogen and Phosphorus Fertilizer. Indian Journal of Agronomy, 48, 133-135.

[19] Cojocariu, L., Moisuc, A., Radu, F., Marian, F., Horablaga, M., Bostan, C. and Sarateanu, V. (2008) Qualitative Changes in Fodder Obtained from Forage Legumes and Lolium multiflourm in the Ecological Conditions of Eastern Europe. Options Mediterraneennes, Series A, 79, 167-171.

[20] Read, J.J., Brink, G.E., Mclaughlin, S. and Stani, K.R. (2011) Nitrogen and Winter Cover Crop Effects on Spring and Summer Nutrient Uptake. Grass and Forage Science, 66, 381-390. http://dx.doi.org/10.1111/j.1365-2494.2011.00792.x

[21] Soleymani, A., Mohamad, H. and Shahrajabian, M.H. (2012) Influence of Nitrogen Fertilizer on Ash, Organic Carbon, Phosphorus, Potassium, and Fiber of Forage Corn Intercropped by Three Cultivars of Berseem Clover as Cover Crops in Semi Arid Region of Iran. International Journal of Biology, 4, 38. 
[22] Dordas, C.A., Vlachostergios, D.N. and Ithourgidis, A.S. (2012) Growth Dynamics and Agronomic-Economic Benefits of Pea-Oat and Pea-Barley Intercrops. Crop and Pasture Science, 63, 45-52. http://dx.doi.org/10.1071/CP11181

[23] Mouriño, F., Albrecht, K.A., Schaefer, D.M. and Berzaghi, P. (2003) Steer Performance on Kura Clover-Grass and Red Clover-Grass Mixed Pastures. Agronomy Journal, 95, 652-659. http://dx.doi.org/10.2134/agronj2003.0652

[24] Fulkerson, W.J., Neal, J.S., Clarc, C.F., Horadagoda, A., Nadra, K.S. and Barchia, I. (2007) Nutritive Value of Forage Species Grown in the Warm Temperate Climate of Australia for Dairy Cows: Grasses and Legumes. Livestock Science, 107, 253-264. http://dx.doi.org/10.1016/j.livsci.2006.09.029

[25] Rizk, T.Y., El-Agroudy, M.H. and Al-Aswad, A.M. (2007) Effect of Irrigation Regimes on Forage Quality and Nutritive Values of Berseem in Binary Mixtures with Barley and Annual Ryegrass. African Crop Science Society Conference, Vol. 8, El-Minia, 27-31 October 2007, 195-199.

[26] Soleymani, A., Shahrajabian, M.H. and Naranjani, L. (2011) The Effects of Nitrogen as Starter Fertilizer on Ash Percentage, Important Elements and Solar Radiation Absorption of Berseem Clover Cultivars Intercropped by Corn. Journal of Food, Agriculture and Environment, 9, 342-344.

[27] Nyamagouda, S.S. and Angadi, S.S. (2002) Effect of Different Proportion of Mixed Seeding on Quality of Forage Maize-Legume Mixfed Cropping System. Kamataka Journal of Agricultural Science, 15, 8-12.

[28] Hathout, M.K., Swidan, F.Z., El-Sayes, M.F. and Eid, H.A. (1997) Quality Evaluation of Feed Resources at the Newly Reclaimed Area in Egypt. Egyptian Journal of Applied Sciences, 13, 80-96.

[29] Lithourgidis, A.S., Vasilakoglou, I.B., Dhima, K.V., Dordas, C.A. and Yiakoulaki, M.D. (2006) Forage Yield and Quality of Common Vetch Mixtures with Oat and Triticale in Two Seeding Ratios. Field Crops Research, 99, 106-113. http://dx.doi.org/10.1016/j.fcr.2006.03.008 
Scientific Research Publishing (SCIRP) is one of the largest Open Access journal publishers. It is currently publishing more than 200 open access, online, peer-reviewed journals covering a wide range of academic disciplines. SCIRP serves the worldwide academic communities and contributes to the progress and application of science with its publication.

Other selected journals from SCIRP are listed as below. Submit your manuscript to us via either submit@scirp.org or Online Submission Portal.
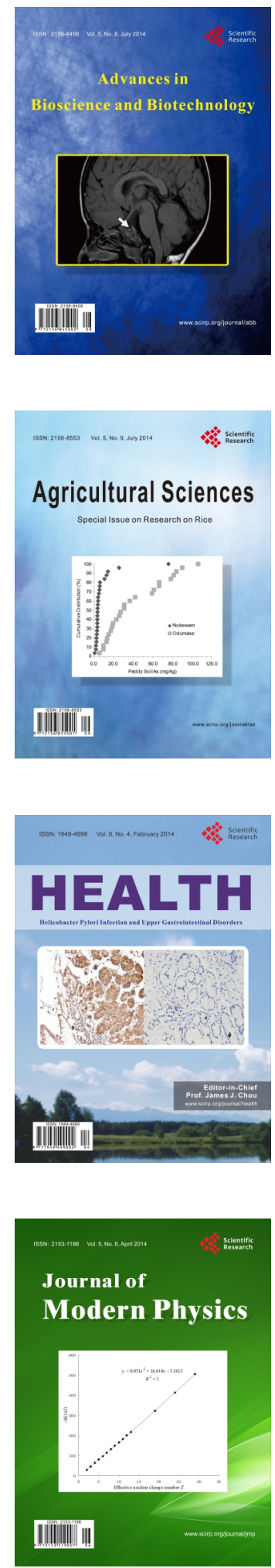
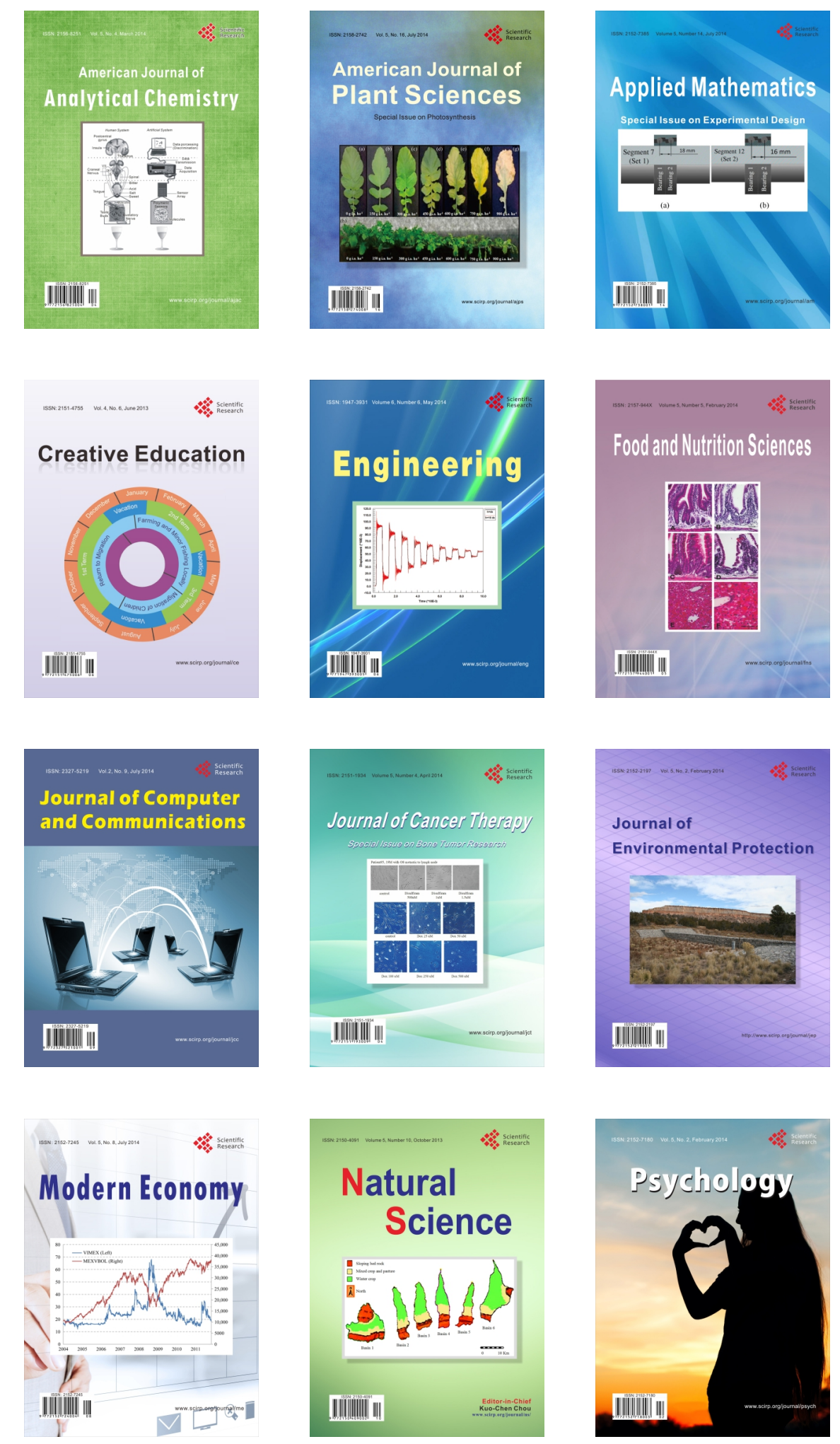